\title{
Conversion Factor of Fuel-Bound Nitrogen to Oxides in the Process of Spruce Wood Combustion in Boiler Grate Furnaces
}

\author{
Ladislav Dzurenda', Juraj Ladomerskýz, Emília Hroncová2, 3* \\ 'Department of Woodworking, Faculty of Wood Sciences and Technology, \\ Technical University in Zvolen, T. G. Masaryka 24, 96053 Zvolen, Slovakia \\ ${ }^{2}$ Department of Environmental Management, Faculty of Natural Sciences, \\ Matej Bel University, Tajovského 40, 97401 Banská Bystrica, Slovakia \\ ${ }^{3}$ Department of Environmental Engineering, Faculty of Ecology and Environmental Sciences, \\ Technical University in Zvolen, T. G. Masaryka 24, 96053 Zvolen, Slovakia
}

Received: 6 June 2014

Accepted: 8 August 2014

\begin{abstract}
This paper presents a procedure for exacly determination the conversion factor of fuel-bound nitrogen to nitrogen oxides in the combustion process of wet spruce wood in boiler grate furnaces with a heat input of 300 to $2,500 \mathrm{~kW}$. They are referred to as fuel-bound nitrogen oxides, thermal nitrogen oxides, and immediate nitrogen oxides. The conversion rate of spruce wood fuel-bound nitrogen is determined based on an analysis of biofuel and emissions-technological measurements of nitrogen oxide concentrations in flue gases from the combustion process of biofuels. For combustion tests, wet spruce chips from 16 sites in Slovakia were used. The value of the conversion factor of spruce wood fuel-bound nitrogen is $\mathrm{X}_{\mathrm{NO}_{\mathrm{x}}}=65.4 \pm 8.3 \%$. The calculated value of the conversion factor of spruce wood fuel-bound nitrogen to $\mathrm{NO}_{\mathrm{x}}$ emissions can be considered fair value, both from the aspect of combustion conditions of spruce chips and made emissions-technology measurements and from the technical calculation itself. It is also declared by the following observations and statements.
\end{abstract}

Keywords: conversion factor, fuel-bound nitrogen, nitrogen oxides, wood, Picea excelsa species, combustion

\section{Introduction}

Nitrogen oxide $\mathrm{NO}_{\mathrm{x}}$ in fuel combustion processes originate from atomic nitrogen chemically bound in organic fuel compounds as well as from air molecular nitrogen, which is supplied to the furnace with combustion air. Up until now, there are three known mechanisms of nitrogen oxide formation: fuel-bound nitrogen oxides, thermal nitrogen oxides, and immediate nitrogen oxides.

*e-mail: emilia.hroncova@umb.sk
Fuel-bound nitrogen oxides are created by the oxidation of nitrogen, which is bound chemically in the fuel with atomic oxygen at temperatures above $500^{\circ} \mathrm{C}[1-5]$.

Thermal nitrogen oxides are produced in the combustion process of fuel by the oxidation of air nitrogen at temperatures above $1,200^{\circ} \mathrm{C}[6]$.

Immediate nitrogen oxides are the product of the oxidation of easily bound nitrogen in fuel, which takes place in a boundary layer at the front part of the flame, with the participation of hydrocarbon radicals at temperatures above $1,600^{\circ} \mathrm{C}[7]$. 
A prevailing part of nitrogen oxides in flue gases from combustion processes of fuels in heat generator furnaces is nitric oxide $\mathrm{NO}$ (about $95 \%$ of total $\mathrm{NO}_{\mathrm{x}}$ ). In a smaller amount, nitrogen dioxide $\mathrm{NO}_{2}$ is created and dinitrogen oxide $\mathrm{N}_{2} \mathrm{O}$, dinitrogen trioxide $\mathrm{N}_{2} \mathrm{O}_{3}$, and dinitrogen pentoxide $\mathrm{N}_{2} \mathrm{O}_{5}$ is created in low concentrations. Since NO in the atmosphere reacts with air oxygen to $\mathrm{NO}_{2}$, in the energy and environmental assessment of fuel sectors, expressing the concentration of nitrogen oxides converted to $\mathrm{NO}_{2}$ is a common practice.

Emission-technological works dealing with nitrogen oxide formation from the exothermic component of fuel combustible: point to the fact that only part of the nitrogen contained in the fuel is oxidized to nitrogen oxides [2-5, 8 , 9]. This principle of oxidation is also used for the combustion of pyrolysis gases.

Research on growing and burning herbaceous and woody energy plants and comparison of the harmful substance emissions into the air while burning these plants is described in papers $[10,11]$.

The aim of this paper is to determine the conversion factor of fuel-bound nitrogen contained in spruce wood biofuel to nitrogen dioxide based on large targeted operating experiments of spruce wood combustion in boiler grate furnaces with a nominal heat input of 300 to $2,500 \mathrm{~kW}$.

\section{Materials and Methods}

\section{Modelling the Conversion of Fuel-Bound Nitrogen to Nitrogen Oxides}

We define the fuel-bound nitrogen conversion factor to emissions of fuel-bound nitrogen oxides $\mathrm{X}_{\mathrm{NO}_{\mathrm{x}}}$ as the percentage ratio of the concentration of nitrogen oxide emissions to the calculated theoretical concentration of nitrogen oxides with determined uncertainty according to equation (1). Since in emission measurements from wood combustion the emissions are corrected to $11 \%$ of the oxygen content in dry flue gases, the calculated concentration is also corrected to the same oxygen content in dry flue gases.

$$
X_{N O_{x}}=\frac{c_{N O_{x}}}{c_{N O_{x}(\max )}} \cdot\left(1 \pm \frac{U_{N O_{x}(\mathrm{rel})}}{100}\right) \cdot 100
$$

The maximum concentration of $\mathrm{NO}_{\mathrm{x}}$ in the flue gases that can be achieved by a $100 \%$ conversion is described by equation:

$$
c_{N O_{x}(\max )}=\frac{m_{N O_{x}(\max )}}{V_{c(\min )}} \quad\left[\mathrm{kg} \cdot \mathrm{m}^{-3}\right]
$$

The value of relative extended uncertainty of determining the conversion factor of fuel-bound nitrogen by a technical calculation at a $95 \%$ level of statistical confidence is given by equation:

$$
U_{N O_{x}}=2 \cdot \sqrt{u_{N O_{x}}^{2}+u_{N O_{x}(\max )}^{2}} \quad[\%]
$$

The value of relative uncertainty of determining the conversion factor of fuel-bound nitrogen by a technical calculation at a $95 \%$ level of statistical confidence is given by equation:

$$
u_{N O_{x}(\max )}=\sqrt{u_{N O_{x}(\text { rel })}^{2}+u_{V_{c}(\text { rel })}^{2}} \quad[\%]
$$

\section{Spruce Chips for Combustion Tests}

For combustion tests, wet spruce chips from 16 sites in Slovakia were used. Energy spruce chips were produced from debarked wood from stands that were not treated by any chemical means, nor was fertilization used during forest cultivation. From the representative samples of chips, wood moisture was taken and an elementary analysis was performed (the content of $\mathrm{C}, \mathrm{H}, \mathrm{N}$ ).

\section{The Industrial Wood Boiler}

Emissions-technological measurements were carried out on modern, fully automated boilers intended for biofuels combustion. Furnaces of Multimiser boilers manufactured by Danstoker, a. s. are designed to burn fuel at a low heat load, thereby creating conditions for the optimum mode for biofuels combustion and a low formation of nitrogen oxide emissions. Similarly, Firematic FR 300 boilers, manufactured by Herz $\mathrm{GmbH}$, ensure the optimum temperature in the furnace for biomass combustion by watercooled grate and electronic control BioControl 3000 for fuel combustion. The results of emissions measurements from spruce chips combustion in another automatic boiler, NKM 1160 M, which has a slightly older design, were similar throughout the power range. With hot-water boilers TPS 35 manufactured by ELBH, s.r.o., similar results were obtained.

\section{Analytical Methods and Emissions Measurements}

\section{Determination of Water Content in the Wood}

Three samples were taken from biofuels prepared in advance for determining the water contents in accordance to EN 14774-2 Solid biofuels - Determination of moisture by the gravimetric method with drying at atmospheric pressure and a temperature of $105 \pm 2^{\circ} \mathrm{C}[12]$.

\section{Determination of $C, H, N$ in the Wood}

Contents of carbon, hydrogen, and nitrogen in spruce wood was performed on the NCS-FLASH EA 1112 analyzer. The oxygen content $\mathrm{O}^{\text {daf }}$ was calculated by neglecting the low concentration of sulphur in spruce wood, thus assuming $\mathrm{S}^{\text {daf }}=0$, according to equation:

$$
O^{d a f}=100-C^{d a f}-H^{d a f}-N^{d a f} \quad[\%]
$$




\section{Emissions Measurement}

The emissions gas concentrations of $\mathrm{O}_{2}$ and $\mathrm{CO}_{2}$ and the emissions contents $\left(\mathrm{CO}, \mathrm{SO}_{2}, \mathrm{NO}_{\mathrm{x}}\right)$ were measured using the continuous emissions monitoring (CEM) techniques by the Horiba ENDA 6000 system. The calibration of gas analyzers was made by calibrated gases $\left(\mathrm{NO}_{\mathrm{x}}\right.$ in $\left.\mathrm{N}_{2}\right)$, in concentration 100-250 ppm, that were supplied by LINDE.

An ENDA 6000 analyzer is a portable on-line analyzer of $\mathrm{CO}, \mathrm{NO}_{\mathrm{x}}, \mathrm{SO}_{2}$, and $\mathrm{O}_{2}$ emissions and further $\mathrm{O}_{2}$ content and temperature of flue gases. For the purpose of determining the conversion factor, only the concentration of nitrogen oxides is important. From the standpoint of the confirmation of quality of combustion, the concentration of carbon monoxide also is important.

Emissions values were determined in a steady state of boilers as mean values of three measurements running every 30 minutes.

The relative standard uncertainty of the weight measurement of nitrogen dioxide in the flue gases during emissions-technology measurements were determined by an ENDA 6000 as $\mathrm{u}_{\mathrm{NO}_{\mathrm{x}}}=5 \%$.

\section{Results}

Measuring the data of burned spruce chip moisture as well as concentrations of nitrogen oxides $\mathrm{NO}_{\mathrm{x}}$ and carbon monoxide $\mathrm{CO}$ in the flue gases from individual boilers for individual emission measurements is shown in Table 1. The mean value of nitrogen oxide $\mathrm{NO}_{\mathrm{x}}$ concentrations, from these emission measurements, was used for calculating an average conversion factor and its uncertainty.

An elementary chemical composition of spruce wood combustible including values of relative standard uncertainty udaf of the determination of individual items of spruce wood combustible are shown in Table 2.

Functional equation (2) for calculating maximum value of fuel-bound nitrogen oxide concentrations in the flue gases $\mathrm{C}_{\mathrm{NO}_{x}(\max )}$ after substituting and modification is shown as:

$$
c_{N O_{x}(\max )}=\frac{3.2857 \cdot \mathrm{N}^{\text {daf }}}{\left[1.8555 \cdot C^{d a f}+1.8905 \cdot V_{\text {air }}\right]} \quad\left[\mathrm{kg} \cdot \mathrm{m}_{\mathrm{nsp} 11 \%}^{-3}\right]
$$

From the calculation of the maximum concentration of nitrogen oxides $\mathrm{NO}_{2}$ in dry flue gases, with an oxygen content in flue gases $\mathrm{O}_{2}=11 \%$, results in $\mathrm{c}_{\mathrm{NO}_{\mathrm{r}}(\max )}=136 \mathrm{mg} \cdot \mathrm{m}^{-3}$.

The conversion rate of spruce wood fuel-bound nitrogen to nitrogen oxides in the combustion process of wood with a moisture $\mathrm{W}^{\mathrm{r}} 28.7$ to $46.3 \%$ in heat generator boiler furnaces with a heat input of 0.3 to $2.5 \mathrm{MW}$ is determined by the following calculation:

$$
\begin{aligned}
& X_{N O_{x}}=\frac{c_{N O_{x}}}{c_{N O_{x}(\max )}} \cdot\left(1 \pm \frac{\left.U_{N O_{x}(r e l)}\right) \cdot 100=\frac{89}{136} \cdot\left(1 \pm \frac{12.7}{100}\right) \cdot 100}{X_{N O_{x}}}=65.4 \pm 8.3 \%\right.
\end{aligned}
$$

Table 1. The average emission concentrations (from three halfhourly mean values) $\mathrm{NO}_{\mathrm{x}}$ and $\mathrm{CO}$ in dry flue gases, with oxygen content in the flue gases $\mathrm{O}_{\mathrm{r}}=11 \%$, from the combustion of spruce chips.

\begin{tabular}{|l|c|c|c|c|}
\hline \multicolumn{1}{|c|}{ Boiler type } & $\begin{array}{c}\text { Boiler } \\
\text { input } \\
{[\mathrm{kW}]}\end{array}$ & $\begin{array}{c}\text { Fuel } \\
\text { moisture } \\
\mathrm{W}^{\mathrm{r}} \\
{[\%]}\end{array}$ & \multicolumn{2}{|c|}{$\begin{array}{c}\text { Emission } \\
\text { concentration } \\
{\left[\mathrm{mg} \cdot \mathrm{m}_{\mathrm{n}}^{-3}\right.}\end{array}$} \\
\cline { 4 - 6 } & $\mathrm{NO}_{\mathrm{x}}$ & $\mathrm{CO}$ \\
\hline MULTIMISER 16 & 880 & 45.2 & 85 & 310 \\
\hline MULTIMISER 15 & 725 & 38.1 & 82 & 346 \\
\hline MULTIMISER 13 & 425 & 44.8 & 78 & 468 \\
\hline MULTIMISER 15 & 725 & 46.3 & 112 & 457 \\
\hline MULTIMISER 15 & 725 & 45.2 & 93 & 521 \\
\hline MULTIMISER 15 & 725 & 44.1 & 88 & 485 \\
\hline MULTIMISER 12 & 350 & 42.8 & 64 & 524 \\
\hline MULTIMISER 15 & 725 & 36.8 & 103 & 531 \\
\hline MULTIMISER 19 & 1750 & 43.8 & 91 & 621 \\
\hline MULTIMISER 13 & 350 & 43.2 & 93 & 527 \\
\hline MULTIMISER 14 & 560 & 41.9 & 81 & 486 \\
\hline FIREMATIC FR 300 & 300 & 40.6 & 79 & 608 \\
\hline FIREMATIC FR 300 & 300 & 41.9 & 86 & 561 \\
\hline FIREMATIC FR 300 & 300 & 42.3 & 98 & 499 \\
\hline NKM 1160 M & 1100 & 32.0 & 89 & 728 \\
\hline TPS 35 & 440 & 28.7 & 108 & 998 \\
\hline Average value [mg·m ${ }_{\mathrm{n}}^{-3}$ ] & & & 89 & 542 \\
\hline Relative standard uncertainty [\%] & & 5.0 & 5.0 \\
\hline
\end{tabular}

\section{Discussion}

The calculated value of the conversion factor of spruce wood fuel-bound nitrogen to $\mathrm{NO}_{\mathrm{x}}$ emissions can be considered fair value, both from the aspect of combustion conditions of spruce chips and made emissions-technology measurements and from the technical calculation itself. It is also declared by the following observations and statements.

The concentration of nitrogen oxides in the flue gases from the dendromass combustion, as shown in Marutzky and Seege [13] and Lin and Murase [14] is also affected by the contamination of the wood by adhesives and chemical wood protection agents containing nitrogen. For the above-mentioned reason, in the targeted experiment chips from sawmill wood cuttings of debarked Picea excelsa species were exclusively burned. Chemical interventions plant treatment - and soil fertilization were not done at the wood felling site in the past, nor during felling. Energy chips can thus be considered a biofuel standard, as evidenced by a comparison of the chemical composition of 
Table 2. Elementary chemical composition of spruce wood combustible.

\begin{tabular}{|c|c|c|c|c|}
\hline \multirow{2}{*}{ Spruce wood } & \multicolumn{4}{|c|}{ Elementary composition of combustible } \\
\cline { 2 - 5 } & $\mathrm{C}^{\text {daf }}$ & $\mathrm{H}^{\text {daf }}$ & $\mathrm{O}^{\text {daf }}$ & $\mathrm{N}^{\text {daf }}$ \\
\hline Proportional representation of element of combustible [\%] & $51.96 \pm 0.52$ & $6.15 \pm 0.15$ & $41.85 \pm 0.42$ & $0.04 \pm 0.002$ \\
\hline
\end{tabular}

combustible burned spruce wood with the chemical composition of wood mass Picea excelsa species, stated by authors $[13,15]$.

All measurements of the concentration of nitrogen oxides in the flue gases for determining the conversion factor were made during a steady state of operation of the combustion installations. This can be declared a minimizing factor of measurement uncertainty from the standpoint of the accuracy of determining the concentration of nitrogen oxides $\mathrm{NO}_{x}$ in the flue gases and the value of the conversion factor.

An important prerequisite for determining the correct value of nitrogen's conversion factor to nitrogen oxides was to ensure that nitrogen fuel oxides were the only thing created. The mentioned prerequisite was ensured by burning spruce wood with a moisture content of $\mathrm{W}^{\mathrm{r}}=23 \%$, in which the adiabatic flame temperature of burning biofuel with combustion air excess $\lambda=2.1$ according to Dzurenda and Jandačka [15]; Dzurenda [16] is below $t_{a d}=1,124^{\circ} \mathrm{C}$. By the combustion of spruce wood chips with a moisture content of $\mathrm{W}^{\mathrm{r}}=32 \div 46.3 \%$, conditions for the formation of high temperature and immediate nitrogen oxides in boiler furnaces were not created. But as the measured values of carbon monoxide $\mathrm{CO}$ concentration in the flue gases show, the creation of fuel-bound nitrogen oxides by a high concentration of carbon monoxide in the furnace combustion chamber [2] also were not limited.

A technical prerequisite to avoid the formation of nitrogen oxides other than nitric oxide in the combustion chamber is the maintenance of excess oxygen in the flue gases above $\lambda=2.0$, which was strictly observed and rigorously checked in emissions-technological measurements.

The determined conversion factor of fuel-bound nitrogen in the combustion process of spruce wood is comparable to the value published by Guzenda and Swigon [8] for wood Scotch pine at a level of $\mathrm{X}_{\mathrm{NO}_{\mathrm{x}}}=67.3 \%$. Stated values can be generalized and also applied for burning wood mass of other coniferous species - low nitrogenous biofuels.

The authors Chrebet et al. $[17,18]$ deal with determining the amount of combustion heat released in the thermal decomposition of Picea excelsa.

In the combustion process of wood from broadleaved species in boiler grate furnaces, which have a 4-6 times higher proportion of nitrogen in combustible biofuel [4, 15], flue gases are formed with nitrogen oxide concentration at the level $\mathrm{C}_{\mathrm{NO}_{\mathrm{x}}}=231-365 \mathrm{mg} \cdot \mathrm{m}^{-3}$. The value of the conversion factor of fuel-bound nitrogen of broadleaved species to nitrogen dioxide $\mathrm{NO}_{2}$ according to the authors Guzenda and Swigon, [8] and Mandl et al. [19] is $\mathrm{X}_{\mathrm{NO}_{\mathrm{x}}}=$ $36-57 \%$. The lower value of the conversion factor of fuelbound nitrogen in the combustion process of broadleaved species is attributed to an increased concentration of nitric oxide NO in the combustion chamber. The mentioned consideration also indirectly confirms the authors' model Pleckaitine and Buinevicius [5] quantifying the value of the conversion factor of the nitrogen contained in fired waste to oxides, stated by mathematical formulation in the form: $\mathrm{X}_{\mathrm{NO}_{\mathrm{x}}}=11.312 \cdot \mathrm{NK}^{-0.6196}$.

\section{Conclusions}

This paper presented the procedure for exact determination of the conversion factor of fuel-bound nitrogen to nitrogen oxides for combustion of wet spruce wood in boiler grate furnaces with a heat input of 300 to $2,500 \mathrm{~kW}$.

The determined value of the conversion factor of fuelbound nitrogen to nitrogen oxides in the combustion of spruce wood in grate furnaces of heat generators is $\mathrm{X}_{\mathrm{NO}_{\mathrm{x}}}=$ $65.4 \pm 8.3 \%$.

From the analysis, results show that $2 / 3$ of the nitrogen contained in the spruce wood oxidizes in the biofuels burning process in the furnaces of heat generators, and $\mathrm{NO}_{\mathrm{x}}$ emissions are exhausted into atmosphere with the flue gas.

\section{Acknowledgements}

This work was supported by the Slovak Research and Development Agency under contract No. APVV-0353-11, "A proposal and realization of a pilot retort with reduced emissions for charcoal production in marginal zone and verification of its application" and Agency VEGA contract No. 1/0547/15 "Experimental measurement and modelling of fugitive emissions.'

\section{Abbreviations}

$\mathrm{X}_{\mathrm{NO}_{\mathrm{x}}}$ Fuel-bound nitrogen conversion factor to emissions of nitrogen fuel oxides (\%)

$\mathrm{c}_{\mathrm{NO}_{\mathrm{x}}} \quad \mathrm{NO}_{\mathrm{x}}$ concentration in flue gases determined by emissions-technological measurements $\left(\mathrm{mg} \cdot \mathrm{m}^{-3}\right)$

$\mathrm{c}_{\mathrm{NO}_{\mathrm{x}}(\max )}$ Theoretical (maximum) concentration of $\mathrm{NO}_{\mathrm{x}}$ in flue gases, created by the perfect oxidation of nitrogen contained in the fuel as determined by technical calculation $\left(\mathrm{mg} \cdot \mathrm{m}^{-3}\right)$

$\mathrm{U}_{\mathrm{NO}_{\mathrm{x}}}$ Relative value of the expanded uncertainty of conversion factor determination of fuel-bound nitrogen by technical calculation at the conventional statistical confidence level of $95 \%$ (\%) 
$\mathrm{m}_{\mathrm{NO}_{\mathrm{x}}(\max )}$ Maximum weight of nitrogen oxides produced by burning $1 \mathrm{~kg}$ wet spruce wood $(\mathrm{kg})$

$\mathrm{V}_{\mathrm{c}(\min )}$ Minimum volume of flue gases produced by burning $1 \mathrm{~kg}$ wet spruce wood according to stoichiometric calculation $\left(\mathrm{mn}^{3}\right)$

$\mathrm{u}_{\mathrm{NO}_{\mathrm{x}}}$ Relative standard uncertainty of the measured weight of nitrogen dioxide in the flue gases during the emission-technology measurements (\%)

$\mathrm{u}_{\mathrm{NO}_{\mathrm{x}}(\max )}$ Relative standard uncertainty of maximum weight of nitrogen dioxide in the flue gases determined by technical calculations (\%)

$\mathrm{u}_{\mathrm{NO}_{\mathrm{x}}(\mathrm{rel})}$ Relative standard uncertainty of the nitrogen dioxide weight in the flue gases $(\%)$

$\mathrm{u}_{\mathrm{V}_{\mathrm{c}(\mathrm{rel})}}$ Relative standard uncertainty of specific flue gases volume $(\%)$

$\mathrm{C}^{\text {daf }}$ Weight portion of carbon in spruce wood combustible (\%)

$\mathrm{H}^{\mathrm{daf}} \quad$ Weight portion of hydrogen in spruce wood combustible (\%)

$\mathrm{O}^{\text {daf }}$ Weight portion of oxygen in spruce wood combustible, $(\%)$

$\mathrm{V}_{\text {air }} \quad$ Stoichiometric volume of combustion air needed for the combustion of $1 \mathrm{~kg}$ dry spruce wood (at $\lambda=1$ )

$\lambda \quad$ Excess of combustion air

\section{References}

1. POHL J. H., CHEN S.L., HEAP M.P., PERSHING D.W. Correlation of $\mathrm{NO}_{\mathrm{x}}$ Emissions with Basic Physical and Chemical Charakteristics of Coal. Proceedings Joint Symposium on Stationary Combustion $\mathrm{NO}_{\mathrm{x}}$ Control, EPRI CS-3182, Electric Power Institute, Palo Alto, CA, pp. 1-30, 1983.

2. NUSSBAUMER T. Requirements for environmentally friendly wood combustion engine. Holz als Roh - und Werkstoff, 49, 445, 1991 [In German].

3. LADOMERSKÝ J. Emission analysis and minimization from the wood waste combustion. Wood Research, 45, (4), 33, 2000.

4. DZURENDA L. Emission of $\mathrm{NO}_{2}$ from the combustion process of wet wood and bark. Drvna industrija, 55, (1), 19, 2004.

5. PLECKAITINE R., BUINEVICIUS K. The factors which have influence on nitrogen conversion formation. Environmental engineering. The $8^{\text {th }}$ International
Conference. Vilnius Gediminas Technical University, pp. 263-269, 2011.

6. ZELDOVIC J. B. Oxidation of nitrogen in the combustion AN, Moskva, pp. 77-79, 1947.

7. FENIMORE C.P. Formation of nitric oxide in premixed hydrocarbon flames. 13-th International Symposium of Combustion. Pittsburg, pp. 224-229, 1971.

8. GUZENDA R., SWIGON J. Technical and environmental aspects of energy utilization of wood and wood waste. Gospodarka paliwami i energia, 45, (1), 20, 1997 [In Polish].

9. SALZMANN R., NUSSBAUMER T. Fuel Staging for $\mathrm{NO}_{\mathrm{x}}$ Reduction in Biomass Combustion: Experiments and Modeling. Energy \& Fuels, 15, (3), 575, 2001.

10. JASINSKAS A., ULOZEVIČUTÉ I., RUTKAUSKAS G. Plant biomass production and use as an environmentallyfriendly local fuel. Pol. J. Environ. Stud., 21, (1), 89, 2012.

11. JUSZCZAK M. Experimental study of pollutant concentrations from a heat station supplied with wood pellets. Pol. J. Environ. Stud., 20, (6), 1519, 2011.

12. EN 14774-2 Solid biofuels - Determination of moisture content - Oven dry method. Part 2: Total moisture Simplified method, pp. 7, 2009.

13. MARUTZKY R., SEEGER K. Energy from wood and other biomass. DRW - Verlag Weinbrenner GmbH \&Co, pp. 430, 1999 [In German].

14. LIN H.C., MURASE Y. Analysis of Evolved Species and Estimation of the Combustion Emissions of PACB and AAC Preservatives Using TGA-IR and CEM Techniques. J. Fac. Agr., Kyushu Univ., 54, (1), 223, 2009.

15. DZURENDA L., JANDAČKA J. The use of biomass energy (Energetické využitie dendromasy). Zvolen: Technical University in Zvolen, 161 p., 2010 [In Slovak].

16. DZURENDA L. Mathematic model for the calculation of the emission value of cmaxNOX for combustion of wet dendromass in grate fire chamber. Acta Facultatis Ecologiae, 19, (1), 49, 2008 [In Slovak].

17. CHREBET T., MARTINKA J., BALOG K., TURNOVA Z. Activation energy of pure and impregnated lignocellulosic materialsobtained by isothermal method. Advanced Materials Research, 291-294, 690-693, 1179-1183, 291-294, 2013.

18. CHREBET T., MARTINKA J., BALOG K., HRUŠOVSKÝ I. Moment of Lignocellulosic Materials Ignition Defined by Critical Mass Flow Rate. Applied Mechanics and Materials, 291-294, 1985, 2013.

19. MANDL C., OBERNBERGER I., BENESCH C., SCHARLER R. Release and conversion of fuel-bound nitrogen during fixed-bed gasification and subsequent staged combustion. 19 $9^{\text {th }}$ European Biomass Conference \& Exhibition, June 2011, Berlin, Germany, ETA-Renewable Energies (Ed.), Italy, 2011. 
